\title{
AC 2010-2104: A MULTINATIONAL 1+2+1 ELECTRICAL ENGINEERING PROGRAM
}

\section{Esteban Rodriguez-Marek, Eastern Washington University}

ESTEBAN RODRIGUEZ-MAREK is an Associate Professor in the department of Engineering and Design at Eastern Washington University. He did his graduate work in Electrical Engineering at Washington State University. He worked as a research scientist at Fast Search \& Transfer before transferring to the Department of Engineering \& Design at Eastern Washington University. His interests include image and video processing, communication systems, digital signal processing, and cryptographic theory and applications.

\section{Min-Sung Koh, Eastern Washington University}

MIN-SUNG KOH obtained his B.E. and M.S. in Control and Instrumentation Engineering in the University of ULSAN, South Korea, and his Ph. D in Electrical Engineering and Computer Engineering at Washington State University. He was with KEPCO (Korea Electric Power Co.) for 9 years before enrolling in the $\mathrm{Ph}$. D. program at Washington State University. In KEPCO, he worked at the NPP (Nuclear Power Plant) as a nuclear engineer. In the Fall '02 quarter he joined the department of Engineering and Design at Eastern Washington University, where he has taught several courses in Computer Engineering Technology and Electrical Engineering. Currently, he is an associate professor of Electrical Engineering at Eastern Washington University. His research interests are in the areas of speech and image signal processing, signal processing in communication systems, photoacoustics, and embedded systems.

\section{Michael Brzoska, Eastern Washington University}

Dr. Michael Brzoska holds a PhD in Mechanical Engineering. He is a Professor and the Associate Dean of Computing and Engineering Sciences at Eastern Washington University. He is an active member of ASME and coordinates the annual Symposium on Applications in Computer Fluid Dynamics.

\section{Claudio Talarico, Eastern Washington University}

Claudio Talarico is an Associate Professor of Electrical Engineering at Eastern Washington University. Before joining Eastern Washington University, he worked at University of Arizona, University of Hawaii and in industry, where he held both engineering and management positions at Infineon Technologies, IKOS Systems (now Mentor Graphics), and Marconi Communications. His research interests include design methodologies for integrated circuits and systems with emphasis on system-level design, embedded systems, HW/SW co-design, system specification languages, and early design assessment, analysis, and refinement of complex SOCs. Talarico received a PhD in electrical engineering form the University of Hawaii at Manoa, and is a member of IEEE. Contact him at ctalarico@ewu.edu 


\title{
A Multinational 1+2+1 Electrical Engineering Program
}

\begin{abstract}
A consortium of American universities and Chinese universities has been formed to make a multinational dual-degree program. All American universities belong to the American Association of State Colleges and Universities (AASCU) and the Chinese universities to the China Center for International Education Exchange (CCIEE). These universities agreed on the policies regarding the program, with the basic foundation being that it is a $1+2+1$ program. While the program applies to various degrees, for Electrical Engineering the $1+2+1$ program implies that Chinese students who have finished basic math and science requirements in China can study for two years at a university in the United States belonging to the consortium, and then return to their home institutions in China to finish their college degrees. Students who participate in this program are awarded degrees from the two institutions the students have attended. Further, each of the AASCU universities choosing to participate in this program makes its own policies, which are also customized in a major-by-major basis. This paper describes the steps taken by the Electrical Engineering Program at Eastern Washington University (EWU) towards planning and implementing the dual degree, which already has been in-place for three years. While providing specifics about Electrical Engineering, a general overview of the program is also included, as well as the lessons learned during the process.
\end{abstract}

\section{Introduction}

The world economy has shifted from a few central foci of highly developed countries to a globalized one where several emerging economies are catching up with first world countries [1]. A few cases distinguish themselves with an even faster pace of economic growth than others, such as China, Singapore, India, South Korea, etc. China has maintained a growth rate close to $10 \%$ in the last few years, as reported by various news organizations, and is expected to surpass the United States as the top economy in the world by 2027 [2].

A part of the rapid growth of the Chinese economy lies in the support given by the Chinese government to the advancement of sciences, math and engineering. As part of this push, the China Center for International Education Exchange (CCIEE) [3] was formed to enhance and promote the cooperation of Chinese with foreign universities. Among the various mandates of 
the CCIEE is the upgrading of the Chinese higher education system to the level of other worldleading countries.

The American Association of State Colleges and Universities (AASCU) [4] is a group of 430 public universities and colleges throughout the United States (and its territories) whose purpose includes providing support for the strengthening of academic quality, while promoting access and inclusion.

The AASCU and the CCIEE have partnered to form a consortium of American and Chinese universities for the purpose of creating a " $1+2+1$ " program, where students from China study their first and last year in China, but travel to the United States for their sophomore and junior years. Upon the successful completion of both the American and Chinese portions of their studies they are awarded degrees by both the American and Chinese universities. The consortium is inclusive to various majors. This paper presents the particular case of Electrical Engineering program at Eastern Washington University, where the $1+2+1$ program has been in-place for three years. Section II presents a brief history of the program. The hurdles overcome to merge the institutional goals with the $1+2+1$ program are presented in Section III, followed by the curriculum in Section IV. Lessons learned and conclusions follow in Section V.

\section{History of the program.}

The Sino-American $1+2+1$ program is based on an agreement for Cooperation in Educational Exchanges signed by China and the United States in 2000. The purpose of the Agreement was to prepare international professionals for the developing Chinese society and economy. Two nongovernmental organizations, CCIEE in Beijing and AASCU in Washington D.C. started the program with seven universities from both countries in 2001. In academic year 2009, the number of participating universities had reached 100. 82 Chinese universities and 18 American universities became partners with 1071 Chinese students having studied in the United States through the Program. 1+2+1 Program is one of the largest and the most successful ChineseAmerican academic programs [5].

The EWU director of Distance and International Education and Outreach was approached by CCIEE in 2004 to see if EWU had an interest in creating a distance education program with China. EWU felt that it had the resources available including appropriate campus attitude, sufficient student services support personnel and broad academic expertise. EWU already had a significant international program in place with Japan, Russia, Thailand, and Taiwan. Resources for international students had been building over the past decade including an excellent English Language Institute (ELI) program and a contingent of international education support personnel. An "international" campus attitude had been building at the same time with faculty and staff beginning to understand all that is involved in enrolling and supporting students from abroad. In 2005, the president of EWU, signed agreements with 11 universities in China making 
EWU the 7th American partner university in Sino-American 1+2+1 Dual-Degree Program. The agreements were "part of a renewed emphasis on international engagement by EWU" [6] due to the reduced enrollments of international students which were affected by new immigration policies after the 9/11 terrorist attack. In 2006, the EWU president signed four more agreements with Chinese universities and expanded the Program at EWU.

Initially the business program began enrolling $1+2+1$ Chinese students and immediately following this, it was determined that electrical engineering was another field of interest. The faculty of the Engineering \& Design (E\&D) Department analyzed the transcripts of several Chinese Universities including Liaoning Shihua University, Xi'an Shiyou University, Nanchang Institute of Aeronautical Technology, and North University of China. It was determined that Chinese students in their first year had finished calculus, linear algebra, and physics. In other words they were generally ready for engineering. Seeing this, the E\&D Department decided to create articulation agreements with the above Chinese Universities. In 2006-07, EWU partnered with 20 Chinese universities and welcomed students from five universities. Our first enrollees generally did well but needed more time to prepare sufficient English backgrounds. As a result of this experience, many of the students now spend more time improving their English proficiency before enrolling in electrical engineering coursework. Agreements had to be set in place between the faculty organization and administration to adjust the required core of general education courses as discussed later in the paper. By 2007-08, EWU served a total of $261+2+1$ Program students. By 2008/9 over forty students were enrolled.

Now, in addition to bringing Chinese students to EWU, EWU is actively exploring avenues for the consortium to provide additional opportunities for faculty and staff exchanges, as well as internships for American students in China. This program holds great promise to open doors for EWU faculty, staff and students, to a country and culture that is becoming increasingly important to the United States. In 2008, EWU accommodated the first visiting scholar of 1+2+1 program and in 2009; EWU welcomed seven visiting scholars from six Chinese partner universities.

\section{Institutional policy}

Eastern Washington University, as well as all other consortium members, has agreed to be contractually bound by the general provisions of the $1+2+1$ dual-degree agreement negotiated between AASCU and CCIEE and by specific programs of study in individual majors articulated by the partner institutions in each country. Students participating in the $1+2+1$ program are bound to all policies of EWU, including admissions and degree requirement policies, although exceptions may be articulated between any two universities. This ensures a seamless transition between institutions, as well as generating uniformity and predictability across institutions in the system. 
A set of general education guidelines (detailed later in this section) were used to establish the articulation agreements between EWU and its Chinese partners. Among the guidelines are university mandated general education requirements, which may be modified if EWU makes changes to its general education requirements. Should this occur, partner institutions, as well as students participating in the program, are made aware of the changes nine months in advance of the date changes are to be effective. Students currently participating in the program have a close relationship both with advisors in the field of interest and counselors provided by the $1+2+1$ program. Typically, students are very carefully advised to ensure a course selection that will enhance their education at EWU.

Although Test of English as a Foreign Language (TOEFL) scores are not required for admission, students will be tested on language proficiency by the EWU's English Language Institute (ELI). Students who do not demonstrate a minimum proficiency enroll in ELI's support courses, and must successfully complete them prior to moving on to their program of study. ELI's coursework typically includes an intensive summer orientation program.

The guidelines used by EWU to establish articulation agreements are classified into the various categories that EWU students also have to fulfill: Mathematics, computer literacy, composition, core requirements, international studies, cultural diversity, and foreign languages. Each one of these will be described in further detail below [7].

\section{Mathematics}

Participating students will be required to satisfy this requirement by:

- course and grade equivalency at their home institution, or

- by placement testing at EWU, or

- by successfully completing the required EWU Mathematics course or courses with at least a 2.0 as required by the major program.

\section{Computer Literacy}

Participating students will be required to satisfy this requirement by:

- course and grade equivalency at their home institution, or

- by clearance testing at EWU, or

- by successfully completing the required EWU computer literacy course CPLA 101 with at least a 2.0/4.0, or CPLA 120 with at least a 2.0.

\section{Composition}


Participating students will be expected to complete the required EWU English 201 composition course with at least a 2.0.

\section{General Education Core Requirements}

All participating students will be required to complete at least one course from each of three lists, Humanities and Fine Arts, Social Science, and Natural Science, unless otherwise agreed to in writing by the particular articulation agreement and with the consent of the chief academic officer at EWU. Selection of one course from each of the three core areas, for a total of at least 15 credits, will be made in consultation with the EWU major program advisor, as students will be undertaking general education coursework at their Chinese university.

\section{International Studies}

All participating students, by virtue of their international student status, will satisfy this requirement.

\section{Cultural Diversity}

All participating students will be required to complete this requirement by either:

- completion of one course from the approved cultural diversity list at EWU, or

- evaluation at the point of admission to EWU of course work from their home institution that is determined to be an equivalent to one of the courses from the approved cultural diversity list at EWU.

\section{Foreign Language}

All participating students will have met this requirement should they pursue a BA degree that requires a foreign language for graduation.

\section{Curriculum}

The ABET accredited Electrical Engineering program at EWU has a typical curriculum involving mathematics, science, and English supporting courses, as well as core and elective engineering offerings. The Capstone Design is the culminating class, involving a major design experience. Students participating in the $1+2+1$ program are assumed to arrive with the following coursework already completed in their home universities:

- 1 year of Calculus

- 1 year of Calculus-based Physics, including laboratories

- 1 quarter of Chemistry, including laboratory

- 1 quarter of computer programming 
With those prerequisites, students are in line with Sophomore level students at the University, allowing them to delve directly into the technical portion of the curriculum. A sample course of study is shown in Table 1. Note that students take their Humanities and Social Science requirements during the Summer quarter.

\begin{tabular}{|c|c|c|c|c|c|}
\hline \multicolumn{6}{|c|}{ Year 2} \\
\hline Fall & Cr. & Winter & Cr. & Spring & $\mathrm{Cr}$. \\
\hline Circuits I & 4 & Circuits II & 5 & Linear Algebra & 5 \\
\hline Calculus IV & 5 & Signals and Systems I & 5 & Signals and Systems II & 5 \\
\hline Differential Equations & 3 & Microelectronics I & 5 & Microelectronics II & 5 \\
\hline Digital Circuits I & 4 & Digital Hardware & 2 & $\begin{array}{l}\text { Microcontroller } \\
\text { Systems }\end{array}$ & 4 \\
\hline Total & 16 & & 17 & & 19 \\
\hline \multicolumn{6}{|c|}{ Year 3} \\
\hline Fall & Cr. & Winter & Cr. & Spring & Cr. \\
\hline Energy Systems & 5 & Technical Elective & 5 & Technical Elective & 5 \\
\hline $\begin{array}{l}\text { Applied Engineering } \\
\text { Electromagnetism }\end{array}$ & 4 & Technical Elective & 5 & Technical Elective & 5 \\
\hline Technical Elective & 5 & $\begin{array}{l}\text { Technology and World } \\
\text { Civilization }\end{array}$ & 4 & Capstone & 4 \\
\hline $\begin{array}{l}\text { Intro to Probability And } \\
\text { Statistics }\end{array}$ & 4 & Technical Writing & 5 & Econ GECR & 5 \\
\hline Total & 18 & & 19 & & 19 \\
\hline
\end{tabular}

Table 1. Sample curriculum for 1+2+1 students at Eastern Washington University.

The coursework shown in Table 1 is very challenging, and $1+2+1$ students can choose to complete some of the coursework, such as technical electives, in their home universities, or during the summer. However, students must complete at least 90 credits at EWU to be awarded a degree from the institution.

\section{Lessons Learned and Conclusions}

After monitoring the development of the $1+2+1$ program for the past three years we are confident that the agreement and policies established with the participant universities are adequate to ensure both the quality of the program and students success. In general, we have noticed that the $1+2+1$ student's background in math and science is of the same breadth and depth as the students that attended US institutions. As a result of our experience with the $1+2+1$ electrical engineering program the major lesson learned is that students' success is directly correlated to their English proficiency. To this end EWU has put in place, through the English Language Institute program, a number of resources to help international students. The ELI is a member of the Commission on English Language Accreditation (CEA), of the consortium of University and College Intensive English Programs (UCIEP) and of the American Association of 
Intensive English Programs (AAIEP) and offers students 5 levels of ad hoc English courses in conversation, listening, reading, writing, grammar, reading and writing for academic purposes, and research papers preparation. Furthermore, in order to facilitate the transition of the $1+2+1$ students to EWU the ELI and the International Education Office provide the possibility to match the $1+2+1$ students with International Peer Advisors, Cultural Mentors and International Advisors. One of the approaches taken to enhance the learning experience of the $1+2+1$ students is a high level of cooperation with native speakers. Towards this end, $1+2+1$ students are encouraged to partner with American students in the various laboratory classes. It was noted that there was a significant improvement in the academic performance both of the $1+2+1$ students and the native speakers. One of the intangible benefits is the intercultural exposure and the diversity that is generated in the classroom.

Besides the well structured agreements between EWU and the participating Chinese universities and the numerous support resources made available to the student, another factor we believe is instrumental in the success of the $1+2+1$ students in the electrical engineering program is the early and regular interaction with faculty, and a good understanding of the dynamics and challenges international students are faced with (more than $80 \%$ of the faculty in the electrical engineering program at EWU have had significant exposure to academic systems in both local and foreign institutions).

\section{Bibliography}

[1] T. Friedman, The world is flat. Farrar, Straus \& Giroux, April 2005.

[2] Newsweek, Issue of March 21, 2009

[3] http://www.cciee.com.cn/english/index.htm

[4] http://www.aascu.org/

[5] Internal EWU Memorandum from the Division of International and Educational Outreach, 2005.

[6] Internal EWU Memorandum from the Division of International and Educational Outreach, 2005.

[7] "Policy on EWU General Education and the China Center for International Education Exchange," approved 2007. 